\title{
Financing Investment under Uncertainty: The Case of Payout Reductions in Globally Listed Maritime Firms
}

\author{
Ioannis Chasiotis' ${ }^{1}$, Maria Giaka ${ }^{2}$, Dimitrios Konstantios ${ }^{3}$, Vasilios-Christos Naoum ${ }^{3}$ \\ ${ }^{1}$ School of Business, Metropolitan College, Athens, Greece \\ ${ }^{2}$ Department of Economics, University of Piraeus, Piraeus, Greece \\ ${ }^{3}$ Department of Maritime Studies, University of Piraeus, Piraeus, Greece \\ Email: ichasiotis@mitropolitiko.edu.gr,giaka@webmail.unipi.gr, konstantios@unipi.gr,vcnaoum@unipi.gr
}

How to cite this paper: Chasiotis, I., Giaka, M., Konstantios, D., \& Naoum, V.-C. (2021). Financing Investment under Uncertainty: The Case of Payout Reductions in Globally Listed Maritime Firms. Theoretical Economics Letters, 11, 1157-1164. https://doi.org/10.4236/tel.2021.116073

Received: October 30, 2021

Accepted: December 6, 2021

Published: December 9, 2021

Copyright (C) 2021 by author(s) and Scientific Research Publishing Inc. This work is licensed under the Creative Commons Attribution International License (CC BY 4.0).

http://creativecommons.org/licenses/by/4.0/

\begin{abstract}
This study explores whether payout reductions represent an alternative source of investment funds. We focus on the distinct, financially constrained maritime sector and draw a sample of 1863 firm-year observations from 143 globally-listed maritime firms during 1987-2020. Investigating the payout reduction-investment nexus, we document a positive relationship that surfaces in recession periods. Our findings indicate that payout reductions represent a source of funds for maritime firms in times of negative external financing shocks.
\end{abstract}

\section{Keywords}

Dividend Payouts, Investment, Uncertainty, Maritime Industry, Recession, Shipping Firms

\section{Introduction}

The association between dividends and investments has attracted a lot of attention in the corporate finance literature (Brav et al., 2005; Bliss et al., 2015; Iyer et al., 2017; Apergis et al., 2021). Earnings distributions reduce cash at hand and therefore limit the funds available for investment. Considering the well-known rigid nature of dividends, concerns have often been expressed regarding the ability of dividend-paying firms to sufficiently fund investment, especially in recession states. In the current study, we aim to explore the dividend reduction-investment nexus in the context of global maritime firms. Specifically, we investigate whether dividend reductions in the maritime sector constitute a source of 
investment capital. The significance of the globalized maritime sector as well as its distinct traits makes such an investigation worthwhile.

The maritime sector plays a vital role in facilitating global trade and is affected by its highly volatile nature (Drobetz et al., 2013). Firms in this sector are characterized by their over-levered and financially constrained profile while exhibiting a high degree of cyclicality and asset risk (Grammenos et al., 2008; Drobetz et al., 2013). Considering the maritime sector's financially-constrained nature, it is important to better understand the investment-dividend reductions relationship. Considering the relevant gap in the literature, such information will allow us to evaluate the ability of maritime firms to finance investment under periods of reduced credit supply and thus their ability to deter underinvestment.

The rigidity of dividends and the adverse market reaction to dividend cuts is well documented in the empirical literature (Lintner, 1956; Brav et al., 2005). Specifically, managers are hesitant to reduce dividends (Allen \& Michaely, 2003). Additionally, dividend payments once initiated are perceived as a commitment to the firm. The quasi-fixed cost nature of dividend payments has been often criticized as being detrimental to capital investment. For example, UK firms are well known for their culture of high and inflexible dividends (Khan, 2006; Reneboog \& Trojanowski, 2011). Thus, the ability of UK firms to secure sufficient investment capital in times of recession when internal capital generative abilities deteriorate has often been a root of concern (see Bond \& Meghir, 1994). In support of such concerns, Chasiotis \& Georgantopoulos (2021) provide evidence that the dividend decision is taken independently from the investment decision in UK-listed firms. Similar evidence is provided by Iyer et al. (2017) for a sample of US firms. On the other hand, theoretical and empirical evidence suggests that payouts may comprise a source of investment capital. The rest of the paper is as follows: Section 2 discusses our methodology, Section 3 presents our data, Section 4 presents our results and Section 5 concludes.

In the presence of asymmetric information, firms prioritize their sources of financing. Myers (1984), names this financing hierarchy as the pecking order theory of financing. According to the pecking order firms prefer internal over external financing. However, as cash flows vary, firms may need to reduce dividends to avoid the use of external capital. Nevertheless, considering the rigidity of dividend payments firms may tap external financing first by using debt the last choice being equity. The reason is that the former carries comparatively fewer information asymmetries. The pecking order theory seems to explain the empirical observation that the most common source of investment capital is internally generated funds (Vernimmen.com, 2011). In the UK, empirical evidence shows that investment is often hampered if internal capital is insufficient (Bond \& Meghir, 1994). Moreover, Bliss et al.'s (2015) findings show that firms appear to use the proceeds from payout reduction to fund investment especially during recessions where access to credit is problematic. Therefore, it is of vital importance to investigate if managers of maritime firms curb dividends to secure in- 
vestment funds. Otherwise, a rigid payout policy, independent from investment, may lead to underinvestment.

Considering this study's objective, we draw insights from Bliss et al. (2015) and regress investment on dividend reductions and a number of control variables. We interact the dividend reduction variable with indicator variables representing periods of macroeconomic and maritime sector recessions. Our empirical findings suggest a positive relationship between payout reductions and investment which holds only in recessions states. This is consistent with the notion that maritime firms use payout reductions as sources of investment funds.

It seems that as earnings and external financing capabilities decline during recessions maritime firms are not reluctant to reduce dividends. The aforementioned behavior seems to be driven by the necessity to secure investment capital. This study improves our understanding of decision-making in the peculiar maritime sector. The degree of flexibility of payout policy can directly influence investment efficiency and financial distress, thus our findings are expected to be useful to researchers, financial analysts and market participants in this sector.

\section{Methodology}

Our research objective is to investigate the payout reduction-investment nexus. In this respect, we follow the approach by Bliss et al. (2015) and regress investment to payout reductions, the interaction term between payout reductions and recessions states, as well as a set of control variables. Specifically, we estimate the following equation:

$$
\begin{aligned}
& \text { Total Investment }_{i t} \\
& =a_{t}+\beta_{1} \text { Recession }_{i t}+\beta_{2}\left({\text { Payout reduction } \times \text { Recession }_{i t}}\right. \\
& +\beta_{3} \text { Payout reduction }_{i t}+\beta_{4} \text { Growth opportunities }_{i t} \\
& +\beta_{5} \text { Cash Flow }_{i t}+\beta_{6} \text { Leverage }_{i t}+\beta_{7} \text { Capex }_{i t}+\mu_{i}+e_{t, t}
\end{aligned}
$$

We estimate Equation (1) using three different estimators. Specifically, we estimate Equation (1) with OLS with robust standard errors clustered at the firm level as well as OLS with high dimensional firm fixed effects and robust standard errors. However, as these estimators often yield biased estimates, we also utilize two-step GMM-in-differences estimators. According to Baltagi (2008), GMM produces unbiased coefficients.

Total Investment is proxied by the sum of capital expenditures and R\&D scaled by lagged total assets. Payout reduction is calculated as the reduction in cash dividends between $t$ and $t-1$ scaled by total assets. Recession is an indicator variable that takes a value of 1 in recession states. We control for CashFlow calculated as the firm's cash flows from operating activities scaled by lagged total assets. We additionally control for Leverage calculated as total debt scaled by total assets and the firms' Growth opportunities calculated as sales growth between year $t$ and $t-1$. Finally, we control for capital expenditures scaled by lagged total 
assets. Variable definitions as well as Compustat Global items are provided in Table A1 appendix.

\section{Data}

Our sample consists of globally-listed firms in the maritime industry and we draw our firm-level data from the Compustat Global database. This database is provided by Standard and Poors and widely used in the finance empirical literature. According to earlier studies we exclude the following firms 1) shipyards and shipping 2) involved passenger shipping, 3) operate drilling ships 4) supply vessels, and 5) inland vessels. Our final sample includes 1863 firm-year observations from 143 maritime firms for the time period between 1987 and 2020. Descriptive statistics highlight the over-levered nature of the maritime sector exhibiting a mean leverage ratio of $44.7 \%$ quite higher than the non-maritime average firm. The average firm in the maritime sector exhibits a yearly sales growth of $11 \%$ and a cash flow ratio of $7.7 \%$. The regress and variable Total investment are on average $12.6 \%$ on our sample while Capital expenditures have a mean equal to $11.3 \%$. Figure 1 shows the number of firms that reduce dividends and the number the firms exhibiting negative free cash flow on an annual basis. It can be observed that the two lines move in tandem suggesting that firms respond to negative cash flows with dividend reductions. A possible explanation could be that when internal funds are insufficient firms reduce dividends in order to secure investment capital. Nevertheless, in order to alleviate concerns that this relationship may be spurious, in the next section we perform regression analysis and assess this behavior further (Table 1).

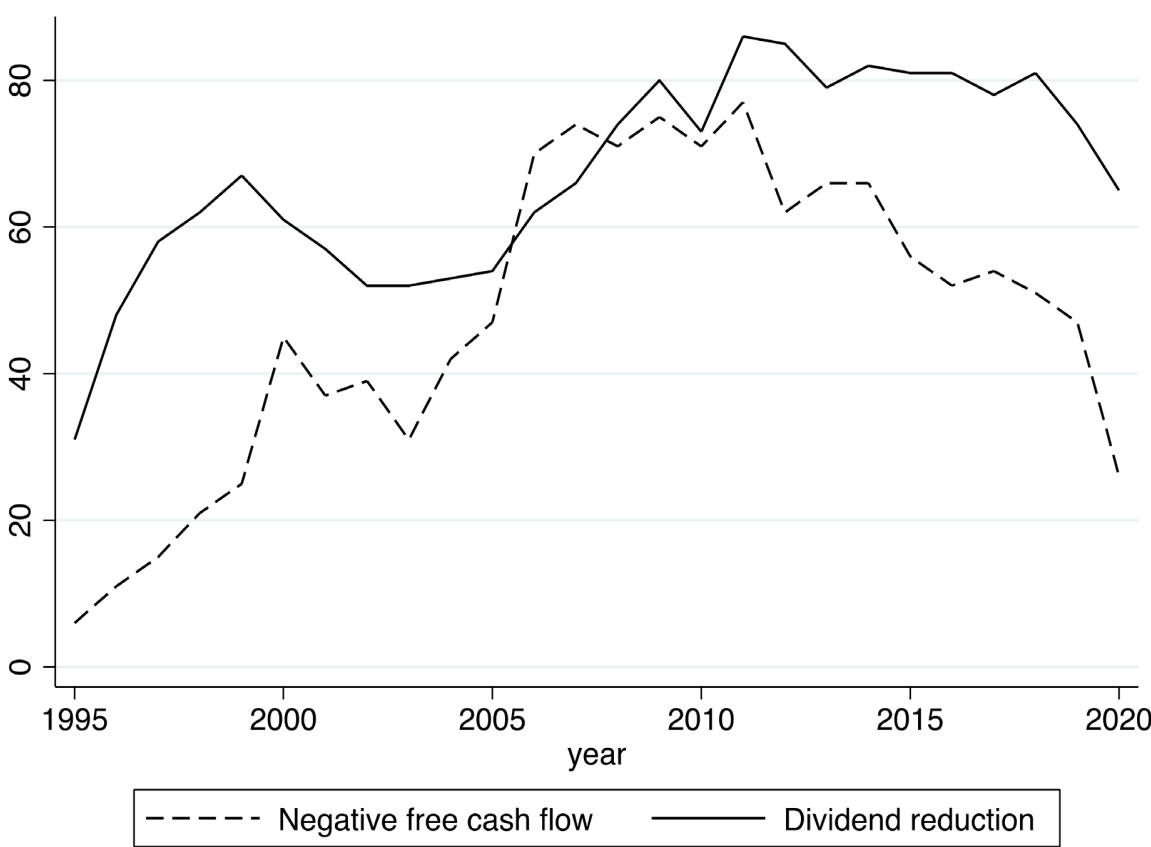

Figure 1. Number of firms exhibiting dividend reductions and negative free cash flows on an annual basis. 
Table 1. Descriptive statistics.

\begin{tabular}{cccccc}
\hline Variable & Obs & Mean & Std. Dev. & Min & Max \\
\hline Total investment & 1863 & 0.126 & 0.148 & 0 & 0.731 \\
Payout reduction & 1863 & -0.001 & 0.015 & -0.077 & 0.062 \\
Growth opportunities & 1863 & 0.109 & 0.588 & -0.987 & 5.655 \\
Leverage & 1863 & 0.447 & 0.243 & 0 & 0.939 \\
Cash Flow & 1863 & 0.077 & 0.116 & -1.038 & 0.488 \\
Capital expenditures & 1863 & 0.113 & 0.138 & 0 & 0.612 \\
\hline
\end{tabular}

\section{Results}

In Table 2, we document our findings considering the relationship between investment and payout reduction. The coefficient of the Recession dummy is negative and statistically significant which indicates that investment spending declined during the recession periods both in the US market and the maritime industry.

When we focus on Payout reduction, we find a negative coefficient; however, its statistical significance is not consistent across all specifications. An insignificant relationship suggests that in non-recessions states the dividend decision is independent of the investment decision. This finding is in line with empirical evidence by Iyer et al. (2017) and Chasiotis \& Georgantopoulos (2021) studies from non-maritime firms. However, the interaction term between the Recession variable and the Payout reductions exhibits a positive and statistically significant coefficient. At this point, it is important to note that the net effect of cash savings from payout (Payout reduction) on total investment is significantly positive (as measured by the sum of the coefficient on Payout reduction and Recession variable $\times$ Payout reductions). Payout reductions appear to be used as a source of funds for investment. Thus, on the net, the importance of payout reductions as a source of funds is evident during the financial crisis period.

\section{Conclusion}

This study explored the use of payout reductions as a potential source of investment capital. Our findings demonstrate a positive relationship between payout reductions and investment. This relationship is apparent in times of recessions both in the macroeconomy and the maritime sector. In recessions, the firm's profitability is hampered thus limiting the firm's capability to finance investment with internal funds. Moreover, access to external capital becomes problematic. Thus, our findings indicate, that in such an environment, managers of maritime firms do not hesitate to curtail dividends to secure investment capital.

Our results indicate that dividends in the maritime sector are less (more) rigid (flexible) than the average non-maritime firm (see Iyer et al., 2017; Chasiotis \& Georgantopoulos, 2021). This distinct dividend behavior is likely to be driven by 
Table 2. Results from estimating equation 1. Column 1 presents results from OLS estimations using robust standard errors clustered at the firm level. Column 2 and Column 3 document the fixed-effects and GMM-diff estimates using robust standard errors, respectively. Panel A (B) refers to maritime (US) recessions.

\begin{tabular}{|c|c|c|c|}
\hline Panel A & $\begin{array}{l}\text { (1) } \\
\text { OLS }\end{array}$ & $\begin{array}{l}(2) \\
\mathrm{FE}\end{array}$ & $\begin{array}{c}(3) \\
\text { GMM-diff }\end{array}$ \\
\hline \multirow[t]{2}{*}{ Payout reduction } & $-0.244^{\star}$ & $-0.231^{\star}$ & -0.147 \\
\hline & $(0.138)$ & $(0.138)$ & $(0.091)$ \\
\hline \multirow[t]{2}{*}{ Pay-out Reduction $x$ Shipping Recessions } & $0.518^{\star *}$ & $0.542^{\star *}$ & $0.322^{*}$ \\
\hline & $(0.210)$ & $(0.216)$ & $(0.181)$ \\
\hline \multirow[t]{2}{*}{ Shipping Recessions } & $-0.060^{* * *}$ & $-0.078^{\star * *}$ & $-0.075^{\star *}$ \\
\hline & $(0.013)$ & $(0.012)$ & $(0.031)$ \\
\hline \multirow[t]{2}{*}{ Growth opportunities } & $0.038^{\star * *}$ & $0.028^{\star * *}$ & $0.014^{* *}$ \\
\hline & $(0.012)$ & $(0.008)$ & $(0.006)$ \\
\hline \multirow[t]{2}{*}{ Leverage $_{t-1}$} & $0.211^{\star * *}$ & $0.317^{\star * *}$ & $0.429^{* * *}$ \\
\hline & $(0.027)$ & $(0.045)$ & $(0.064)$ \\
\hline \multirow[t]{2}{*}{ Cash Flow } & $0.358^{\star * *}$ & $0.347^{\star * *}$ & $0.145^{\star}$ \\
\hline & $(0.079)$ & $(0.100)$ & $(0.080)$ \\
\hline \multirow[t]{2}{*}{ Capex $_{t-1}$} & $0.321^{\star * *}$ & $0.190^{* * *}$ & $0.091^{\star * *}$ \\
\hline & $(0.049)$ & $(0.051)$ & $(0.034)$ \\
\hline \multirow[t]{2}{*}{ Constant } & $-0.040^{* * *}$ & $-0.061^{\star * *}$ & \multirow{4}{*}{1863} \\
\hline & $(0.011)$ & $(0.022)$ & \\
\hline Observations & 1863 & 1863 & \\
\hline R-squared & 0.300 & 0.251 & \\
\hline Firm fixed effects & $\mathrm{NO}$ & YES & YES \\
\hline \multirow{2}{*}{ Panel B: } & $(1)$ & (2) & (3) \\
\hline & OLS & FE & GMM-diff \\
\hline \multirow[t]{2}{*}{ Payout reduction } & -0.230 & -0.211 & $-0.331^{\star}$ \\
\hline & $(0.140)$ & $(0.171)$ & $(0.180)$ \\
\hline \multirow[t]{2}{*}{ Pay-out Reduction $x$ US Recessions } & $0.658^{* *}$ & $0.566^{*}$ & $0.916^{*}$ \\
\hline & $(0.282)$ & $(0.290)$ & $(0.535)$ \\
\hline \multirow[t]{2}{*}{ US Recessions } & 0.000 & -0.001 & -0.020 \\
\hline & $(0.015)$ & $(0.009)$ & $(0.041)$ \\
\hline \multirow[t]{2}{*}{ Growth opportunities } & $0.038^{\star * *}$ & $0.030^{\star * *}$ & $0.039^{* *}$ \\
\hline & $(0.012)$ & $(0.009)$ & $(0.016)$ \\
\hline \multirow[t]{2}{*}{ Leverage $_{t-1}$} & $0.212^{\star * *}$ & $0.301^{* * *}$ & $0.287^{\star * *}$ \\
\hline & $(0.027)$ & $(0.039)$ & $(0.073)$ \\
\hline
\end{tabular}




\begin{tabular}{lccc} 
Continued & & & \\
\hline Cash Flow & $0.354^{\star * *}$ & $0.417^{\star * *}$ & $0.241^{\star *}$ \\
& $(0.079)$ & $(0.091)$ & $(0.110)$ \\
Capex $_{\text {t-1 }}$ & $0.319^{\star * *}$ & $0.238^{* * *}$ & 0.042 \\
& $(0.049)$ & $(0.050)$ & $(0.044)$ \\
Constant & $-0.040^{* * *}$ & $-0.080^{\star * *}$ & \\
& $(0.011)$ & $(0.020)$ & \\
Observations & 1863 & 1863 & 1863 \\
R-squared & 0.300 & 0.366 & \\
Firm fixed effects & NO & YES & YES \\
\hline
\end{tabular}

the particularly over-levered financial constrained nature of maritime firms. This study increases further our understanding of financial decision-making in the idiosyncratic maritime industry. At this point, we would like to note that our results can be generalized to the universe of listed firms operating in the maritime sector. Thus, an interesting avenue for further research would be to explore and contrast, if possible, the financial behavior of private versus listed maritime firms.

\section{Conflicts of Interest}

The authors declare no conflicts of interest regarding the publication of this paper.

\section{References}

Allen, F., \& Michaely, R. (2003). Payout Policy. In G. M. Constantinides, M. Harris, \& R. M. Stulz (Eds.), Handbook of the Economics of Finance (Vol. 1, Part 1). Elsevier. https://doi.org/10.1016/S1574-0102(03)01011-2

Apergis, N., Chasiotis, I., Georgantopoulos, A. G., \& Konstantios, K. (2021). The Integration of Sharere Purchases into Investment Decision Making: Evidence from Japan. International Review of Financial Analysis, 78, Article No. 101950. https://doi.org/10.1016/j.irfa.2021.101950

Baltagi, B. H. (2008). Econometric Analysis of Panel Data. John Wiley \& Sons.

Bliss, B. A., Cheng, Y., \& Denis, D. J. (2015). Corporate Payout, Cash Retention, and the Supply of Credit: Evidence from the 2008-2009 Credit Crisis. Journal of Financial Economics, 115, 521-540. https://doi.org/10.1016/j.jfineco.2014.10.013

Bond, S., \& Meghir, C. (1994). Financial Constraints and Company Investment. Fiscal Studies, 15, 1-18. https://doi.org/10.1111/j.1475-5890.1994.tb00194.x

Brav, A., Graham, J. R., Harvey, C. R., \& Michaely, R. (2005). Payout Policy in the 21st Century. Journal of Financial Economics, 77, 483-527. https://doi.org/10.1016/j.jfineco.2004.07.004

Chasiotis, I., \& Georgantopoulos, A. G. (2021). The Flexibility of Corporate Payouts vis-à-vis Capital Investment: Some UK Evidence. International Journal of Managerial Finance. https://doi.org/10.1108/IJMF-10-2020-0516 
Drobetz, W., Gounopoulos, D., Merikas, A. G., \& Schröder, H. (2013). Capital Structure Decisions of Globally-Listed Shipping Companies. Transportation Research Part E: Logistics and Transportation Review, 52, 49-76.

https://doi.org/10.1016/j.tre.2012.11.008

Grammenos, C. Th., Nomikos, N. K., \& Papapostolou, N. C. (2008). Estimating the Probability of Default for Shipping High Yield Bond Issues. Transportation Research Part E: Logistics and Transportation Review, 44, 1123-1138. https://doi.org/10.1016/j.tre.2007.10.005

Iyer, S. R., Feng, H., \& Rao, R. P. (2017). Payout Flexibility and Capital Expenditure. Review of Quantitative Finance and Accounting, 49, 633-659. https://doi.org/10.1007/s11156-016-0603-z

Khan, T. (2006). Company Dividends and Ownership Structure: Evidence from UK Panel Data. The Economic Journal, 116, C172-C189. https://doi.org/10.1111/j.1468-0297.2006.01082.x

Lintner, J. (1956). Distribution of Incomes of Corporations among Dividends. Retained Earnings and Taxes. The American Economic Review, 46, 97-113.

Myers, S. C. (1984). The Capital Structure Puzzle. The Journal of Finance, 39, 574-592. https://doi.org/10.1111/j.1540-6261.1984.tb03646.x

Reneboog, L., \& Trojanowski, G. (2011). Patterns in Payout Policy and Payout Channel Choice. Journal of Banking and Finance, 35, 1477-1490.

https://doi.org/10.1016/j.jbankfin.2010.10.028

Vernimmen.com (2011). Letter No. 61 of October 2011.

http://www.vernimmen.com/Read/Vernimmen_Letter/Letter_61.html

\section{Appendix}

Table A1. Variable definitions.

\begin{tabular}{|c|c|c|}
\hline Variables & Description & $\begin{array}{l}\text { Compustat } \\
\text { items }\end{array}$ \\
\hline Total investment & $\begin{array}{l}\text { Capital expenditures plus R\&D scaled by the lagged } \\
\text { book value of total assets }\end{array}$ & capx, $x r d$, at \\
\hline Leverage & $\begin{array}{l}\text { Long term and current debt scaled by the book value of } \\
\text { total assets }\end{array}$ & dllt, dlc, at \\
\hline Cash flow & $\begin{array}{l}\text { Cash flow from operations by the lagged value of total } \\
\text { assets }\end{array}$ & oancf, at \\
\hline $\begin{array}{l}\text { Growth } \\
\text { opportunities }\end{array}$ & Net sales growth calculated $\left(\right.$ sales $_{t}-$ salest $\left._{-1}\right) /$ sales $_{t-1}$ & sale \\
\hline $\begin{array}{l}\text { Capital } \\
\text { expenditures }\end{array}$ & $\begin{array}{l}\text { Capital expenditures scaled by the lagged book value of } \\
\text { total assets }\end{array}$ & capx, at \\
\hline Payout reduction & Cash dividends in year $\mathrm{t}$ minus dividends in year $\mathrm{t}$ & dvc \\
\hline
\end{tabular}

